\title{
AUDIT SERVICES MARKET: THE EXPERIENCE OF UKRAINE
}

\author{
Yaroslavna Mulyk ${ }^{1}$
}

\begin{abstract}
The purpose of the paper is to study the current state of the audit services market in Ukraine, identifying problems and making suggestions for its improvement in terms of European integration. Methodology. General scientific economic and mathematical methods (analysis, synthesis, abstraction, concretization) as well as special methods (comparison, tabular) were used. Results. Audit is one of the important types of services and is becoming increasingly important. It is established that nowadays audit has a number of contradictions and problems. Imperfect regulation of audit market in Ukraine led to problems in confirming the quality and reliability of financial reporting, which increases the risk of bankruptcy of enterprises and banks and reduces the level of confidence in them from potential investors and the public, and also creates obstacles to attract investment in the national economy as a whole. Analysis of audit services market in Ukraine shows a significant differentiation in the number of auditing entities and the cost of their services. There is a decrease in the number of subjects of audit activities, while the cost of services increases. The influence of the regional factor is significant, which led to the greatest concentration of the audit services market in certain regions. In general, the trends of audit development can be described as diversification of audit services with a gradual increase in their volume and value. Practical implications. As a result of the study the priority directions of development of the domestic market of audit services have been identified. Improving the chances of financial success of the subjects of audit activities is provided primarily by improving the quality of audit services performed by professional staff and expanding their range using specialized audit software, as well as the development of industry audit techniques. Provision of audit services to the client, taking into account the requirements of international standards, EU legislation, the application of best practices in the field of auditing, the specifics of the client will increase interest in the audit.
\end{abstract}

Key words: audit, audit activity, audit services, audit quality, audit market, audit reform.

JEL Classification: M40, M42, M48

\section{Introduction}

In the context of the processes of globalization and integration with the European community, Ukraine is faced with the task of harmonizing national legislation in order to adapt it to European norms. This applies in particular to the legislation governing auditing activities in the country and the organization of its management. Audit serves as a reliable way to confirm the financial statements, which is necessary as the company itself, and its shareholders, suppliers, creditors, investors, fiscal authorities, insurance companies and society as a whole, so the development of audit services in Ukraine is relevant. The current state of development and structural transformation of the national economy require and imply the transformation of social relations. This directly affects the improvement of methods and procedures for auditing activities in Ukraine.

A significant contribution to the development of domestic audit was made by: S.V. Bardash, V.V. Holovach, N.I. Dorosh, T.G. Kaminska, O.A. Petryk, N.M. Proskurina, O.Yu. Redko, V.S. Rudnytskiy, L.O. Sukhareva, N.S. Shalimova, M.M. Shihun, I.K. Drozd, L.V. Gutsalenko and others. The following scientists pay considerable attention in their works to the development and reform of the audit in Ukraine: M.T. Bilukha, F.F. Butynets, V.G. Hetman, G.M. Davydov, V.P. Zavgorodniy, V.S. Rudnytskiy, I.I. Pylypenko, N.G. Zdyrko, etc. The above-mentioned scientists devote their work to the development of audit, the search for ways to improve the audit, the problems of quality control of audit services in 
Ukraine, etc. In general, the analysis of scientific literature shows the focus of research on determining the nature of the audit and its types, the use of audit techniques for certain types of business activities, the use of international auditing standards and the improvement of audit methodology, the development of audit quality control system. However, issues related to the development and reform of the audit now require a more detailed and in-depth study, given the current situation.

\section{The role of audit in Ukraine and the problems of its development}

In an unstable and fiercely competitive environment, audits are of great importance, through which companies can assess their situation and position, as well as obtain recommendations for further action.

According to the Law of Ukraine "On the Audit of Financial Reporting and Auditing Activities", auditing activities is interpreted as auditors' and subjects' of audit activities independent professional activity, registered in the Register of auditors and subjects of audit activities on the provision of audit services. Audit of financial statements is defined as an audit service to verify the accounting data and indicators of financial statements and/or consolidated financial statements of a legal entity or representative office of a foreign business entity or other entity that submits financial statements and consolidated financial statements of the group, in order to express an independent auditor's opinion on its compliance in all material respects with national regulations (standards) of bookkeeping, International Financial Reporting Standards or other requirements. Audit services are considered to be auditing, reviewing financial statements, consolidated financial statements, performing other assurance tasks, and other professional services provided in accordance with international auditing standards (On the Audit of Financial Reporting and Auditing Activities: Law of Ukraine, 2017).

The Law of Ukraine "On the Audit of Financial Reporting and Auditing Activities", which entered into force on October 1, 2018, is based on the positions of Directive 2006/43 / EC and Regulation 537/2014, which regulated the 2016 audit reform in the EU, and reinforces requirements for the audit and the process of preparing and disclosing financial statements of companies, as well as the corporate governance system and interaction with auditors. Its implementation will harmonize national legislation on auditing financial statements and audit activities with EU legislation in the relevant field, will promote the development of auditing in Ukraine, increase the investment attractiveness of the national economy (Mulyk, 2020).

Thus, audit is one of the tools, that helps to develop international relations, as it provides confidence in in the confirmed financial information for users at different levels (international, state, business).

In order to successfully develop audit activities in Ukraine, first of all, it is necessary to solve a number of problems associated with the professional activities of auditors and audit companies.

It should be noted that in the economic literature, authors identify various problematic aspects of audit services. So, Gutsalenko L.V. highlights the following: imperfect methodological and theoretical developments in the field of audit control; lack of sufficient audit experience; insufficient number of qualified auditors; auditors' failure to comply with the quality of audit services; lack of fines and sanctions for unreliable audit reports; low trust in the auditor; lack of a clear mechanism for pricing audit services; lack of methodological recommendations for computerization of auditing (Gutsalenko, 2011).

Pavlenova K.O., in addition to the above mentioned, highlights several problems associated with the development of auditing in Ukraine: a significant negative impact of the "shadow" business, the lack of experience of auditing in comparison with other European countries, the negative impact of literal translation of foreign standards and concepts without regard to the specific economic development of Ukraine; insufficient number of qualified audit staff, which is primarily due to the inconsistency of training of Ukrainian bookkeepers and auditors to modern practice requirements; public professional organizations of bookkeepers are not mass, so it complicates the process of discussion and resolution of problematic issues of accounting and auditing practice; lack of a common, generally accepted, economically justified method of pricing of auditing services (Pavlenova, 2009). 
Tomchuk O.V., Zdyrko N.G. also highlight a number of problems and drawbacks that accompany the development of audit in Ukraine. It is worth to note that not highlighted by other authors: the lack of clear and unambiguous terminology, which is the basis for understanding the essence of the audit, its place, tasks and role in the system of economic control; revision of the Code of Professional Ethics of Auditors, especially in terms of liability of audit firms and auditors; lack of a clear framework for regulating the organization and development of internal audit of any Ukrainian enterprise; contradiction of ISA positions with the Ukrainian principles of accounting; lack of internal developments on the organization and methods of internal audit at the enterprise; inefficiency of the current regulatory framework in the field of audit; imperfect certification system; lack of quality control of domestic audit (Tomchuk and Zdyrko, 2017).

Analysis of these sources shows that the problematic issues that need to be overcome and solved in the development of auditing, have been identified by many scientists. But before considering the directions of reforming and development of audit, here are some data about the state of audit in Ukraine.

\section{Analysis of the audit services market in Ukraine}

As practice shows, in Ukraine as of December 31, 2020 2,713 people had a valid auditor's certificate. The dynamics over the past 7 years is shown in Figure 1. As you can see, in 2020 there were 74 less people than in 2014.

The comparative characteristics of the audit market by the total number of auditing entity (hereinafter - AE) and the total volume of services provided in 2014-2020 are presented in Figures 2 and 3.

According to the Law № 2258 (On the Audit of Financial Reporting and Auditing Activities: Law of Ukraine, 2017), AEs can provide audit services only after their inclusion in the Register of Auditors and Subjects of Audit Activities.

According to the legislation, the Register of Auditors and Audit Entities is an automated system for collecting, accumulating, protecting, recording and providing information on auditors and audit entities, which have the right to conduct audit activities in Ukraine.

It consists of the following sections: (1) auditors; (2) auditing entities; (3) auditing entities entitled to perform a mandatory audit of financial statements; and (4) auditing entities entitled to perform a mandatory audit of financial statements of public interest entities (On the Audit of Financial Reporting and Auditing Activities: Law of Ukraine, 2017).

As of December 31, 2020, there were 893 AEs on the registry, including 851 audit companies and 42 individual entrepreneurs.

In general, the indicators of the state of the market of audit services in Ukraine for 2014-2020 are shown in Table 1. Analysis of the results of audit activities and the state of the audit services market shows that the audit market suffers from changes in the country.

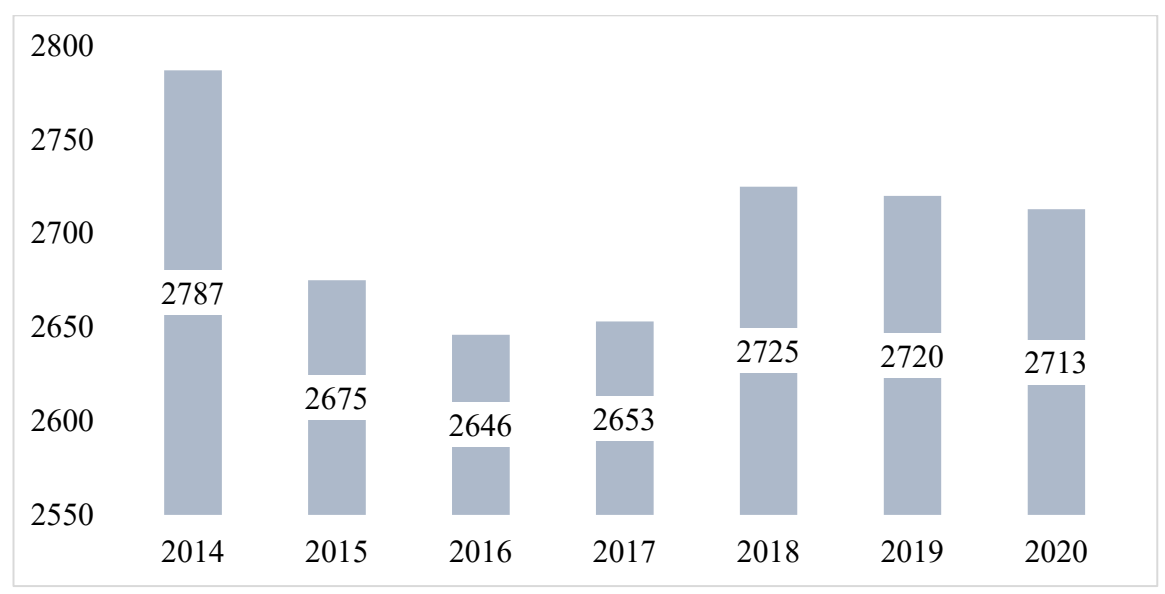

Figure 1. Certified auditors

Source: formed by the author on the basis of

(Information on the State of Auditing in Ukraine (2018 and 2020)) 


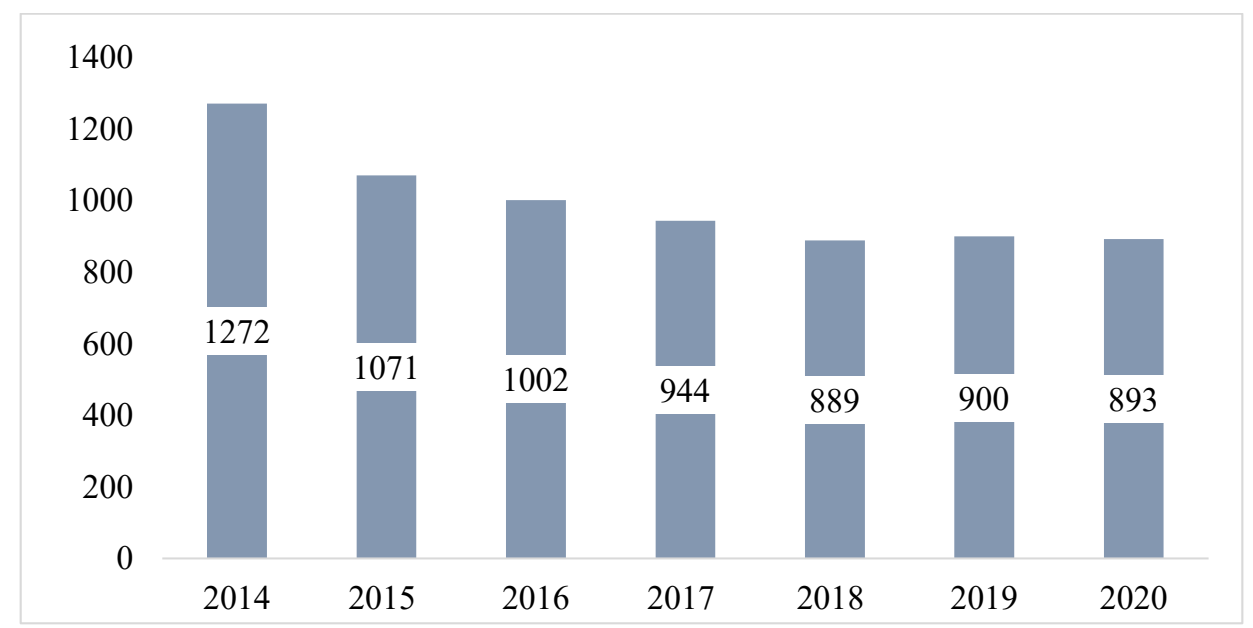

Figure 2. Characteristics of the audit market by the number of AEs in 2014-2020, units

Source: formed by the author on the basis of

(Information on the State of Auditing in Ukraine (2018 and 2020))

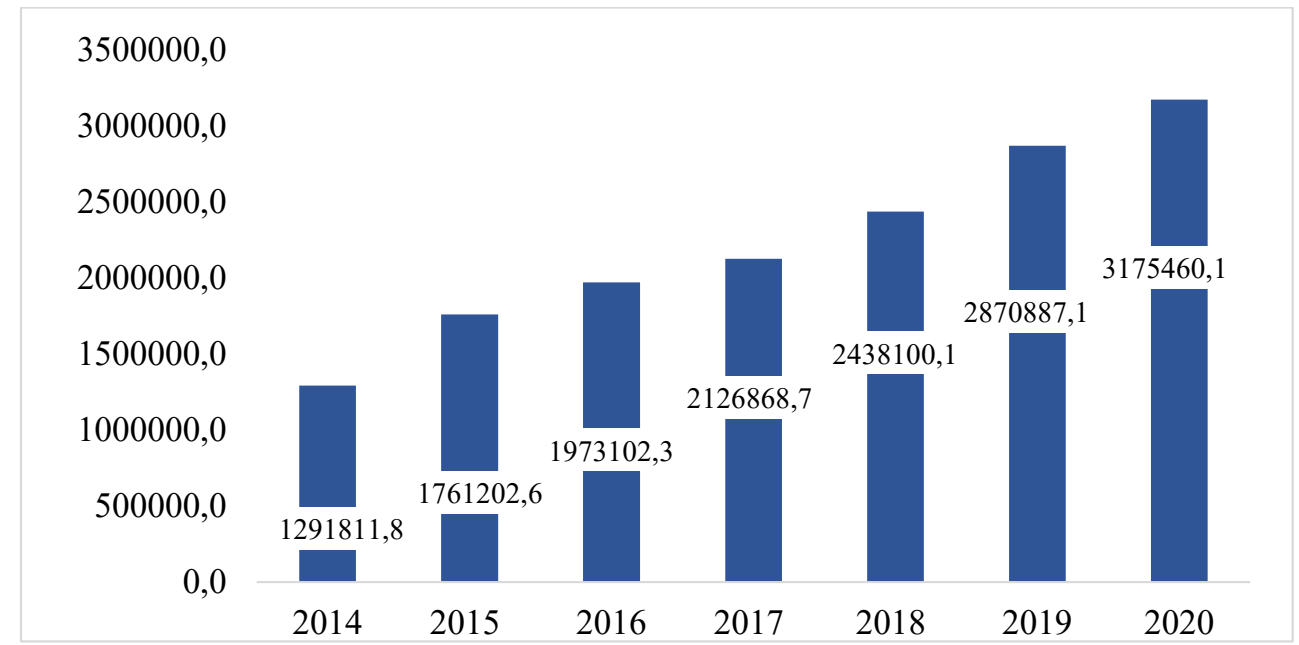

Figure 3. Characteristics of the audit market in the context of the total volume of services provided in 2014-2020, thousand UAH

Source: formed by the author on the basis of

(Information on the State of Auditing in Ukraine (2018 and 2020))

The data show that the dynamics of the number of auditors and audit companies is decreasing $(-74 ;-379)$, which indicates an outflow of business entities from the profession due to a number of factors, including the crisis in society, increased requirements to the auditing profession from the regulatory authorities and changes in legislation.

Comparison of the volume and quantity of services according to the information provided by the $\mathrm{AE}$ in the reports on services provided in 2019-2020, shows that while the number of completed assignments decreased by 1811, the volume of services provided increased by
304,583.0 UAH. In 2020, the Audit Chamber of Ukraine (hereinafter - ACU) received $877 \mathrm{AE}$ reports.

During the analyzed period there is a steady tendency to increase the income of auditing entities, despite the fact that their number is constantly decreasing. In Ukraine in 2020 audit services were provided for a total amount of 3,175.5 million UAH. Between 2014 and 2020, taking into account the decrease in the number of auditing entities, the average annual income per auditing entity increased.

The indicator "Number of Orders Per Unit of Subject" in 2020, compared to 2014, increased 
Table 1

Indicators of the audit services market in Ukraine in 2014-2020

\begin{tabular}{|c|c|c|c|c|c|c|c|c|}
\hline \multirow{2}{*}{ Indexes } & \multicolumn{7}{|c|}{ Years } & \multirow{2}{*}{$\begin{array}{c}\text { Deviation } \\
+,-\end{array}$} \\
\hline & 2014 & 2015 & 2016 & 2017 & 2018 & 2019 & 2020 & \\
\hline Number of auditors, persons & 2787 & 2675 & 2646 & 2653 & 2725 & 2720 & 2713 & -74 \\
\hline Number auditing entities & 1272 & 1071 & 1002 & 944 & 889 & 900 & 893 & -379 \\
\hline Number of reports submitted to the ACU & 1272 & 1071 & 1002 & 944 & 889 & 886 & 877 & -395 \\
\hline Number of orders, units & 5104 & 5642 & 5552 & 4428 & 2496 & 3244 & 31433 & -3671 \\
\hline Number of orders per unit of subject, units & 27,6 & 33,3 & 35,5 & 36,5 & 36,6 & 36,9 & 35,2 & 7,6 \\
\hline Volume of services provided, UAH million & 1291,8 & 1761,2 & 1973,1 & 2126,9 & 2438,1 & 2870,9 & 3175,5 & 1883,7 \\
\hline The average cost per order, thousand UAH & 36,8 & 49,4 & 55,5 & 61,8 & 75,0 & 86,4 & 101,0 & 64,2 \\
\hline
\end{tabular}

Source: formed by the author on the basis of (Information on the State of Auditing in Ukraine (2018 and 2020))

by 7.6 units. Audit services provided by auditing entities in 2020 are distributed quite unevenly in Ukraine.

The structure of the distribution of orders by type of audit services in 2020 is as follows (Figure 4):

- confidence tasks - 57\% (1 795 846.8 UAH);

- related services - 7\% (235 966.3 UAH);

- non-audit services - 36\% (1 143 647.0 UAH).

By order type, consulting services were in greatest demand in 2020 (50\%), 20\% of which were tax advice and 30\% were bookkeeping. Other types of audit services reach $18 \%$. The least demanded were services for the restoration of accounting and representation of the client's interests on accounting, auditing, taxation in state bodies, organizations or courts. In 2020, the volume of services provided by the auditing entites has generally increased, compared with 2014 (Information on the State of Auditing Activities in Ukraine (2018 and 2020)).

Now in Ukraine there is a multi-level system of auditor certification, which provides for certification of the following series:

- "A-1" has restrictions on audits of medium and large firms for first-time qualifiers;

- "A-2" has restrictions on audits at large companies for auditors who have practiced continuously and have upgraded their qualifications annually;

- "A-3" certificate, which is designed to provide a full range of auditing services to businesses of all sizes and types of activity;

- "A-4" is designed for auditors with a higher economic or legal education (Prokhorov and Yukhimenko, 2019).

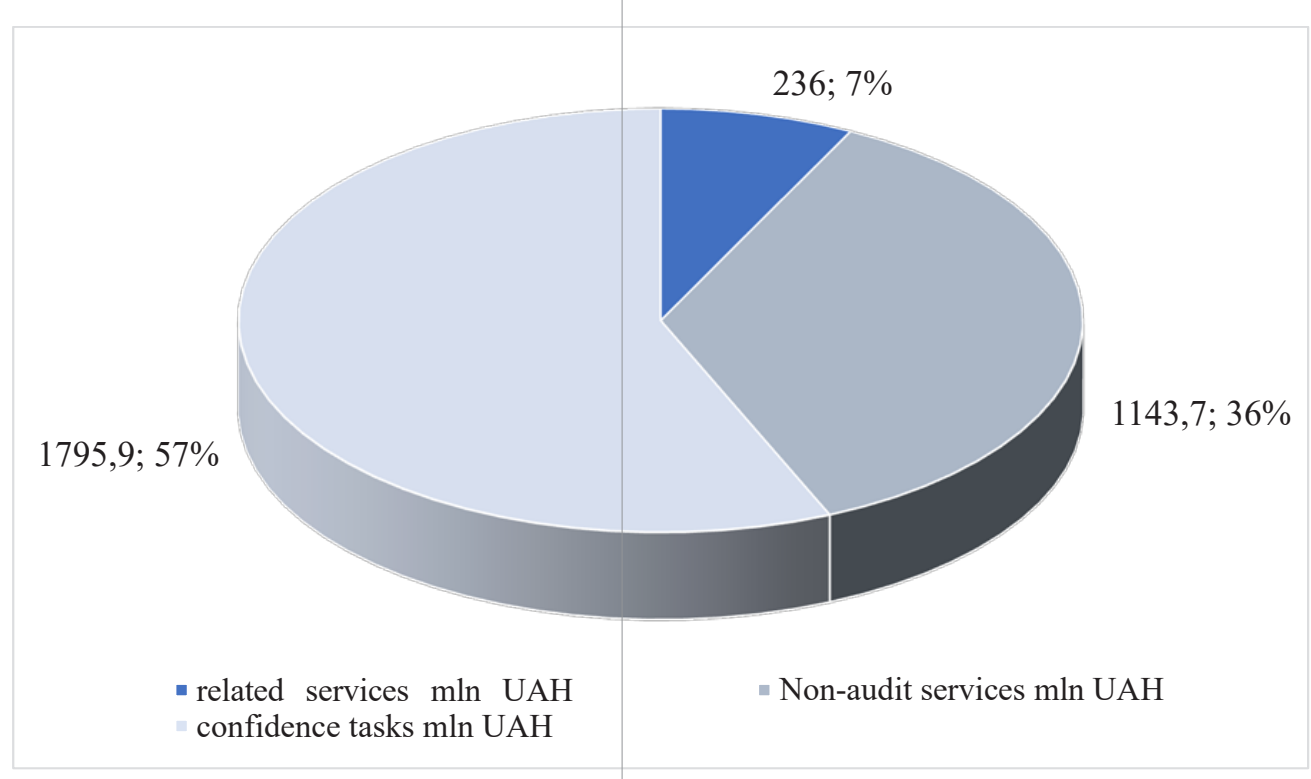

Figure 4. The structure of the distribution of audit services in 2020

Source: formed by the author on the basis of (Information on the State of Auditing in Ukraine (2020)) 
The quality of audit services is of great importance in the process of auditing. In Ukraine, after the entry into force of Law 2258, control over the quality of audit and audit services, which include not only auditing but also the provision of other audit services, is carried out not only by the ACU, but, above all, the established Audit Public Oversight Body of Ukraine. Therefore, control over the quality of the audit will be their responsibility.

In accordance with the Law of Ukraine "On the Audit of Financial Reporting and Auditing Activities", quality control of audit services of the subjects of audit activities is carried out by checking the quality of audit services $\mathrm{AE}$ for compliance with international auditing standards, independence, effectiveness of internal control system of quality of audit services, compliance with the requirements of the Law.

Mandatory quality control of audit services is carried out in relation to:

1) auditing entities, providing services for mandatory audit of financial statements of large enterprises, banks, professional participants of the stock market and issuers the securities of which are admitted to trading on stock exchanges or securities of which are publicly placed (once every three years);

2) auditing entities providing services of mandatory audit of financial statements, in addition to the ones specified in paragraph 1 of this part (once every six years) (Procedure for Audits to Control the Quality of Audit Services, 2019).

Thus, the analysis of the audit services market in Ukraine for the period from 2014 to 2020 shows a significant differentiation in the number of auditing entities and the cost of their services. In particular, there is a decrease in the number of AEs, and the cost of services increases. The influence of the regional factor is also significant, which led to the highest concentration of the audit services market in Kyiv and Kyiv region. At the same time, changes in legislation regarding the right to conduct a mandatory audit of financial statements, as well as the mandatory audit of financial statements of subjects of public interest, has led to structural changes in the list of services provided by auditors. In general, trends in the development of auditing can be assessed as a diversification of audit services with a gradual increase in their volume and value.
Considering the above, it is necessary to implement measures that will promote the development and reform of auditing activities in Ukraine.

\section{Development of the audit services market}

It should be noted that the scientific literature proposes various directions of improvement and development of audit, which can have positive consequences for increasing its effectiveness.

Prokhorova L.I. and Yukhimenko E.S. highlight the following measures: minimization of errors and fraud at the enterprises-customers of audit services; promotion of better results of general fiscal policy; rationalization of approach to spending of budget funds on maintenance of control and auditing apparatus; effective management of cash flows, in particular those related to budget revenues (Prokhorov and Yukhimenko, 2019).

Platonova I.A. proves the necessity of the following directions of development of effective audit: in order to overcome the problems of organizing and conducting external inspections of the quality of auditing firms, in our opinion, it is necessary to improve planning, including the establishment of clear criteria for selecting the object of control; development of appropriate measures to improve the qualifications of specialists performing external quality control; in order to ensure the publicity of the results of external quality control for free access offer on the official site of the ACU on the Internet and in professional publications to publish annual reports on the external quality control of audit firms and auditors; enhancing cooperation between professional audit organizations of Ukraine and international and European professional organizations of accountants and auditors; development of a mechanism for the practical application of ISA in Ukraine, creating comments to them in full; development of standard methods of auditing the financial statements of enterprises by type of their activities on the basis of generalized practical experience of international and domestic audit firms; development of a pricing mechanism for auditing and audit services, based on the study of international experience on this issue; focusing the efforts of professional organizations on such areas of their activities as supporting and expanding the qualifications of their members, 
monitoring quality and independence, popularizing the profession in society, including such fundamental principles as independence, honesty, objectivity (Platonova, 2011).

Oneshko S.V., Viter S.A. and Viremeychik A.M. propose to systematize audit processes using Agile-technologies, which will allow to rationally use the results of each auditor's study and make the audit more flexible in accordance with newly identified problems and situations at the enterprise. The authors also believe that the organizational learning culture initiated by auditing companies would quickly prepare specialists for the relevant operating conditions and take into account the specifics of work in different fields. Retraining all auditors in e-commerce auditing will not only allow them to draw conclusions about financial results, but also to implement recommendations to improve the cash flow management of businesses that trade online or develop software products. In their view, the development and use of unified systems of analysis and auditing, which would focus on key issues, would allow accounting and auditing in accordance with international practices and realities in Ukraine. Improvement of system of publicity of audit results is possible through establishment of unified web-site that would allow analysts to get information about audit results in free access without limitation (Oneshko, Viter, Viremeychik, 2021).

In principle, the research of scientists' opinions on the development and reforming of audit in Ukraine are quite similar and overlap with each other. They relate directly to the introduction and organization of the audit, the work of auditors and their interaction with clients, effective state regulation of this activity, international communication in the field of auditing.

It is believed that the implementation of the audit reform in Ukraine will contribute to creating a positive investment climate in Ukraine, in particular, will increase the level of investor confidence in the financial statements of domestic enterprises; increase confidence in the activities of national auditors; prevent the provision of substandard auditing services, and will promote transparency and reliability of financial statements of securities issuers, banks, insurance companies, and other public companies and will open Ukrainian auditors access to European markets.

\section{Conclusions}

Auditing is an important service and is becoming increasingly important. It is a reliable method of confirming financial statements. For auditing to play a key role in society, it is advisable to raise it to an appropriate level of quality, independence and ethical principles. The last stage in the development of national audit began with the adoption of the Law of Ukraine "On the Audit of Financial Reporting and Auditing Activities," which aims to bring the rules of national legislation on auditing in line with EU rules and legislation.

Having studied the peculiarities of im plementation and the main trends of audit development in Ukraine, it can be said that currently the audit has a number of contradictions and problems. Imperfect regulation of audit market in Ukraine has led to problems in confirming the quality and reliability of financial statements. In turn, this increases the risk of bankruptcy of enterprises and banks, which reduces the level of confidence in them on the part of potential investors and the population, and also creates obstacles to attracting investment in the national economy as a whole.

Analysis of the market of audit services in Ukraine shows a significant differentiation in the number of auditing entities and the cost of their services. In particular, there is a decrease in the number of auditing entities, and the cost of its services, in turn, increases. The influence of the regional factor is significant, resulting in the highest concentration of the audit services market in certain regions. At the same time, changes in legislation regarding the right to conduct a mandatory audit of financial statements, as well as a mandatory audit of the financial statements of public interest entities, led to structural changes in the list of services provided by auditors. In general, trends in the development of auditing can be described as a diversification of audit services with a gradual increase in their volume and value.

According to the results of the study it is possible to determine the priority directions of development of the domestic market of audit services. Improving the chances of financial success of the AEs is ensured primarily by improving the quality of audit services provided by professional staff and expanding their range through the use of specialized audit software, 
as well as mastering industry methodologies. Providing audit services to the client, taking into account the requirements of international standards, EU legislation, the use of best practices in the field of auditing, the specifics of the client, will increase interest in the audit. The prospect of further research is to improve the provision of audit services on the basis of priority foreign practices in the context of the policy of European integration of the country.

\section{References:}

Pro audyt finansovoji zvitnosti ta audytorsjku dijaljnistj [On the Audit of Financial Statements and Auditing Activities]: Law of Ukraine of 21.12.2017 no. 2258-V111. Available at: https://zakon.rada.gov.ua/go/2258-19.

Mulyk, Ya. (2020). Audytorsjka dijaljnistj v Ukrajini: suchasnyj stan, reformuvannja ta rozvytok [Audit activities in Ukraine: Current Situation, Reform and Development]. Agrosvit, 7, 37-47. DOI: https://doi.org/10.32702/2306-6792.2020.7.37

Gutsalenko, L. V. (2011). Audyt v Ukrajini: rozvytok, problemy ta shljakhy jikh vyrishennja [Audit in Ukraine: Development, Problems and Solutions]. Innovative economy, 20, 97-101.

Platonova, I. A. (2011). Problemy ta perspektyvy audytu v Ukrajini [Problems and Prospects of Auditing in Ukraine]. Scientific Bulletin of Poltava University of Economics and Trade. Series: Economic Sciences, 4(2), 337-341.

Pavlenova, K. O. (2009). Suchasni problemy ta perspektyvy rozvytku audytu v Ukrajini [Current Problems and Prospects of Audit Development in Ukraine]. Available at: http://www.rusnauka.com/ 23 D 2009/Economics/49916.doc.htm

Tomchuk, O. V., \& Zdyrko, N. G. (2017). Suchasnyj stan i tendenciji rozvytku audytorsjkoji dijaljnosti v Ukrajini [The Current State and Trends in the Development of Auditing in Ukraine]. Economy. Finances. Management: Current Issues of Science and Practice, 4, 32-42.

Informacija pro stan audytorsjkoji dijaljnosti v Ukrajini u 2018 roci [Information on the State of Auditing in Ukraine in 2018]. Audit Chamber of Ukraine. Available at: https://www.apu.com.ua

Informacija pro stan audytorsjkoji dijaljnosti v Ukrajini u 2020 roci [Information on the State of Auditing in Ukraine in 2020]. Audit Chamber of Ukraine. Available at: https://www.apu.com.ua

Prokhorova, L. I., \& Yukhimenko, E. S. (2019). Suchasnyj stan i tendenciji rozvytku audytorsjkoji dijaljnosti v Ukrajini [Analysis of the Current State and Problems of Reform and Development of Auditing in Ukraine on the Basis of International Experience]. Young Scientist, 6(2), 205-210.

Porjadok provedennja perevirok z kontrolju jakosti audytorsjkykh poslugh [Procedure for Conducting Inspections to Control the Quality of Audit Services]: Order of the Ministry of Finance of Ukraine of August 29, 2019, no. 362. Available at: https://zakon.rada.gov.ua/laws/show/z1026-19

Zdyrko, N. G., \& Mulyk, Ya. I. (2019). Derzhavnyj finansovyj kontrolj v systemi zabezpechennja ekonomichnoji bezpeky derzhavy [State Financial Control in the System of Economic Security of the State]. Economy. Finances. Management: Current Issues of Science and Practice, 7, 112-122.

Oneshko, S. V., Viter, S. A., \& Viremeychik, A. M. (2021). Strateghija rozvytku audytu v umovakh cyfrovoji ekonomiky [Audit Development Strategy in a Digital Economy]. Investments: Practice and Experience, 15, 64-69. DOI: https://doi.org/10.32702/2306-6814.2021.15.64

Mulyk, T. O., Maternal, O. A., \& Plonsak, O. L. (2017). Analiz ghospodarsjkoji dijaljnosti [Analysis of Economic Activity]. Kyiv: Center for Educational Literature. (in Ukrainian)

Pravdyuk, N. L., Mulyk, T. O., \& Mulyk, Ya. I. (2019). Upravlinnja finansovoju bezpekoju pidpryjemstv: oblikovo-analitychnyj aspekt [Management of Financial Security of Enterprises: Accounting and Analytical Aspect]. Kyiv: Center for Educational Literature. (in Ukrainian) 